\title{
A LETTER TO A DISCOURAGED SUNDAY-SCHOOL TEACHER.
}

\author{
By MYRA REYNOLDS, \\ The University of Chicago.
}

THERE are some teachers, I suppose, who would do well to be discouraged. It would be a mark of grace and indicate progress. Such teachers, however, go lightly and smoothly on. Mentally and spiritually their equipment is too meager for any painful recognition on their part of the actual poverty of their teaching. By dint of prizes and picnics they keep things up to a tolerable average in the way of promptness and attendance, and by dint of lively discussions of athletics or dress maintain a certain amount of interested attention, and they are not concerned at the lack of results more profound and farreaching. But you do not belong to that class. Discouragement is for you a real hindrance to effective work. Reckoning up one's failures is always a dismal kind of arithmetic, and for a person naturally selfdepreciating is stultifying as well. The slough of despond may be wholesome for some people, but for you its air is malarial. As a permanent attitude toward one's work self-doubt means the loss of freedom, hope, enthusiasm, and it finally means defeat. Hence discouragement should be vigorously fought down. But how shall this be done?

One way is by reflecting on the true use of an ideal. Your description of a successful class as one each member of which accepts Christ as his leader and grows from week to week in a sympathetic understanding of the Bible, and in a more vital and discriminating application of Christian principles to life, is a representation of what a class might be if teacher, pupils, and conditions were themselves ideal and ideally related. Such a conception is a shining vision by which the teacher may be inspired and directed. But for everyday use we seem to need a kind of second-best, compromise ideal that saves us from despair by bringing results to the test, not of perfection, but of the possible under existing, hampering conditions. You cannot afford to bate a jot of your high ideal, but I wish you could learn to use it as Ernest did the Great Stone Face in Hawthorne's story. Then your ideal would be an influence permeating and molding your life and thought, but not a 286 
footrule against which you anxiously measure brief stages of progress. Even an imperfect approach to your ideal should give you joy. In work that has to do with human character results are always fragmentary and seldom distinctly traceable. Christ was a great teacher. Paul was a great teacher. But the immediate result of their teaching must have been often most disheartening. If an ideal is a high one, it must inevitably be a distant one, and in that case failure to secure immediate results is not a legitimate ground for discouragement.

A second way of fighting down discouragement is by refusing to allow your mind to remain enveloped in a haze of difficulty, and by seeking out definite points of difficulty upon which there may be an intelligent concentration of effort. To see the exact point of failure is to go half way toward success.

For example, you say that your boys refuse to be interested in the regular lessons. Well, then, since you cannot change the nature of the boys, can you not teach these lessons from a point of view better suited to the needs of the boys? Or, better still, can you not arrange a series of lessons especially fitted to their stage of development? Boys of fifteen are usually interested in men whose lives have been marked by heroic and stirring adventure. Why not seek to enter the boy's mind by this obviously open door? Very lively and profitable, discussion might grow out of a study of Peter, John, Matthew, Paul, Silas, Timothy, and others, trying to answer in each case just two questions : What qualities or deeds in this man's life were heroic? What ones fall short of heroism? A series of Old Testament characters would need much more cautious, though not less frank, study. To estimate a life in an age so unlike our own we must cultivate the historical imagination and reproduce the setting of that life. With that caution a series of Old Testament characters could be made stimulating and ethically and spiritually wholesome. But I should not confine my list to men of Bible times. Carey, Judson, John G. Paton, Father Damien are typical of a line of heroes that boys would find both fascinating and inspiring. Then we might add such men as Clarkson and Wilberforce and Shaftesbury, or such women as Elizabeth Fry and Clara Barton - indeed, the beautiful, long, inspiring list of men and women who have depended on God for strength and guidance, and who have put their lives at the service of their fellow-men. Such study could be enlivened in many ways. Outline maps, relief maps, pictures of men and places could be effectively used. Then special topics assigned to each boy for class reports on customs, climate, character of inhabitants, peculiar difficulties 
to be surmounted, etc., in the places under discussion; or arguments on disputed points of character; or two-minute presentations of opinions in summary of a debatable question - these and the many other methods that experience and originality may suggest will be a help to securing alert attention and a sense of personal responsibility for the work. It would help to clearness of impression if notebooks were kept in which were entered under each character his list of heroic qualities and deeds. After a time a kind of general description of a hero could be constructed as an ideal by which to test one's own life.

It would be well, too, now and then, to study people who are not heroes, and find the secret of failure. Such contrasting studies would be most illuminating. And somewhere late in the course such pictures as those of Tennyson's King Arthur and Wordsworth's Happy Warrior, or his Leech-Gatherer, and many others that would suggest themselves, might be profitably brought in. I suppose it might be said that in such teaching you are not holding strictly to the Bible for your material; but if the work is done with the right spirit and purpose, if the central idea is always to relate actual life and thought to the Christian conception of character, it cannot fail to be supremely religious. 'This, however, is but one suggestion. Many other schemes might be put into practical shape, the guiding thought always being the adaptation of the work to the boy.

But this work in the class, however valuable, is probably subordinate in value to the work that may be done out of the class. By a genuine friendship and comradeship with the boys a teacher can go far toward overcoming the most discouraging features of the problem before her. A class of boys fifteen years old should certainly have a kind of club or fraternity organization with elected officers who carry actual responsibility concerning class management. Every effort should be made to stimulate the feeling that the class is a unit, that the shame or honor of one member reflects on all. A just pride in the reputation of the class as generous, fair-minded, intelligent, should be cultivated. To attain this end the class should have some united interest aside from the Sunday session. Suppose they formed themselves into an Agassiz club. Suppose the teacher had a room-any sort of room not too fine or inaccessible - which should be the club- or reading-room of the class. There could be kept the books on heroes, reference-books, the Agassiz books and papers; there the boys could keep specimens of any sort; there could be the formal meetings of the 
club for reports and plans; and there they could go informally for study or talk. The social life of the club could also center there. There the teacher could learn to know the boys on the genuine footing of real life. Out of the interests awakened here would come many other sorts of companionship; walks over the hills, tours of investigation, pleasant hours of reading together. Some such personal relation, close, sincere, varied in opportunity, gives the teacher insight into a boy's real thoughts and needs, and gives incalculable force to what she says on Sunday. Then, too, she might well associate herself with her class in some active benevolent or civic work. There is hardly a community in which boys could not do work that would be a real contribution toward securing better social conditions, and the kind of interest thus aroused would be invaluable for the boys themselves.

I am well aware that such work as is here outlined both in the class and out of it makes great demands upon the teacher. But the successful class belongs only to the teacher who puts herself into her work. High ideals are not attained without sacrifice. And a work so great as the right management of a class of boys at an important formative period of their lives is worth all the mind and heart and time one can devote to it. 